\title{
DETERMINATION OF SHAFT ROTATION ANGLE FROM ACCELERATIONS OF THE WIRELESS SENSOR BY THE NOVEL NUMERICAL METHOD
}

\author{
V.V. Sinitsin, sinitsinvv@susu.ru, \\ N.M. Yaparova, iaparovanm@susu.ru \\ South Ural State University, Chelyabinsk, Russian Federation
}

\begin{abstract}
The scheduled maintenance allows us to prevent breakdowns and unplanned downtime of equipment but limits the flexibility of manufacturing systems. On the other hand, condition monitoring concept enhances the manufacturing systems flexibility but requires reliable diagnostic information in real-time. Modern technologies, e.g., wireless power and Industrial Internet of Things (IIoT), allow implementing high-sensitivity sensors such as the Wireless Acceleration Sensor (WAS) for condition monitoring. The WAS is mounted on a machinery rotating shaft and the WAS measures angular, linear accelerations and angle of the shaft simultaneously. Moreover, the WAS contains a high-performance microcontroller, which allows processing measured data and estimating machinery condition in real-time. However, the accuracy of the angle measurement by the WAS significantly affects the accuracy of linear accelerations measurement by the WAS. In this paper, the authors propose the novel numerical method which allows us to measure accurately of a rotation angle and linear accelerations of the shaft. The method is based on a regularization technique and application of finite-difference equations. Besides, the study shows the results of simulation at applying the numerical method to calculate the rotation angle of the shaft using measurement data, which contain noise, obtained from the wireless accelerations sensor. The simulation results show that the numerical method effectively determines the rotating angle and the method is robust to noise.

Keywords: angular acceleration, rotating shaft, wireless sensor, numerical method, regularization method, inverse problem.
\end{abstract}

\section{Introduction}

The scheduled maintenance allows us to prevent breakdowns and unplanned downtime of equipment but limits the flexibility of manufacturing systems. On the other hand, condition monitoring concept enhances the manufacturing systems flexibility but requires a reliable diagnostic information in real-time. Traditionally, accelerometers mounted on a housing of a mechanism are used to receive diagnostic information. Nevertheless, the received data need special techniques of signal processing to diagnosis, for example, low-energy defects [1-3] or machines with variable workloads [4-5]. Unfortunately, these methods have a limitation of machine fluctuation speed or require a high level of computational resources.

Modern technologies associated with concept Industrial Internet of Things (IIoT) such as wireless technologies (transfer of power and data) and MEMS-technologies allow a substantial increase in the opportunities of implementing sensors in various fields, such as structural health monitoring $[6,7]$ and condition monitoring $[8,9]$. An example of the wireless technologies for condition monitoring is Wireless Acceleration Sensor (WAS) [10]. The WAS is mounted on a machinery rotating shaft and the WAS measures angular, linear accelerations and angle of the shaft simultaneously. However, the accuracy of angle measurement significantly affects the accuracy of linear accelerations measurement.

This paper investigates a problem of calculating the rotation angle of the shaft from the measured angular acceleration of the shaft. The significant feature of the problem is an instability resolve. For that reason, various methods are applied for stabilization of the solution.

At present, development of numerical methods for solving inverse problems is of great interest to many researches. Chinchalkar [11] proposed a numerical method for determining the location of a crack in a beam of different depths based on the finite-element method. Also, Zhang [12] used the finiteelement method for detecting delamination in composites. On the other hand, reducing original problem to integral or integro-differential equation is a generally used method for resolving first-order differen- 


\section{Краткие сообщения}

tial equation. Jang [13] reduced the differential equation of motion to the nonlinear integral equation and found the regularization method for the integral equation. Also, Parand [14] used Volterra's Population Model which was presented as integro-differential equations. The authors considered two common collocation approaches based on radial basis functions for resolving the equations.

The present study offers a numerical method to resolve differential equations for calculating the rotation angle of the shaft from indirect measurement. The method applies explicit finite-differential scheme. Also, the authors used a regularization technique for stabilization of solution. Additionally, the method is robust to noise.

\section{Statement of the problem}

The mathematical model of the wireless sensor, which is reported in [15], is described by the equation system

$$
\left\{\begin{array}{l}
a_{1}(t)=\ddot{\varphi}(t) r+\ddot{x} \cos \left(\varphi(t)+\frac{\pi}{3}\right)-\ddot{z}(t) \sin \left(\varphi(t)+\frac{\pi}{3}\right)+g \sin \left(\varphi(t)+\frac{\pi}{3}\right) ; \\
a_{2}(t)=\ddot{\varphi}(t) r-\ddot{x} \cos (\varphi(t))+\ddot{z} \cos (\varphi(t))-g \sin (\varphi(t)) ; \\
a_{3}(t)=\ddot{\varphi}(t) r+\ddot{x} \cos \left(\varphi(t)-\frac{\pi}{3}\right)-\ddot{z}(t) \sin \left(\varphi(t)-\frac{\pi}{3}\right)+g \sin \left(\varphi(t)-\frac{\pi}{3}\right),
\end{array}\right.
$$

where $a_{1}(t), a_{2}(t), a_{3}(t)$ - acceleration measured by accelerometers of the wireless sensor, $\ddot{\varphi}$ - angular acceleration of the shaft, $\ddot{x}$ and $\ddot{z}$ - linear accelerations of the shaft, $\varphi$ - rotation angle of the shaft, $g$ - gravitational acceleration, $r$ - the distance between the rotational axis of the shaft and the sensitive axis of the accelerometer. Furthermore, the important feature of applying the sensor is incompleteness of initial data which are needed for calculating the instantaneous rotation angle of the shaft.

The initial angle of the shaft can be certainly defined from the signals of the wireless sensor. Accordingly, the initial angle is $\varphi(0)=\varphi_{0}$. However, the initial angular speed of the shaft is an arbitrary value. As a result, the existing methods for calculating the shaft rotation angle are unstable.

Furthermore, the noise of the measurement is a significant feature of the problem described above. Therefore, in this study, the authors presumed that instead of the exact $a_{1}(t), a_{2}(t)$ and $a_{3}(t)$ we know the values with noise $a_{1 \delta}(t), a_{2 \delta}(t), a_{3 \delta}(t)$ and the allowable error estimate $\delta$. Thus, the problem to calculate rotation angle $\varphi(t)$ from (1) under condition that measured values $a_{1}(t), a_{2}(t)$ and $a_{3}(t)$ which contain noise.

\section{Numerical method}

The section contains the main idea of the numerical method to resolve of the system (1). Direct relationship equation between the unknown function $\ddot{\varphi}(t)$ and measured results is shown as [15]

$$
\left\{\begin{array}{l}
\ddot{\varphi}(t)=\frac{a_{1}(t)+a_{2}(t)+a_{3}(t)}{3 r} ; \\
\varphi(0)=\varphi_{0} .
\end{array}\right.
$$

The equations system (2) contains important features. At first, the right hand side of the equation is implicitly depends on the required function $\varphi(t)$. Secondly, $\dot{\varphi}(0)$ is arbitrary value. The first feature leads to essential increase in error of the classical numerical resolve due to small increase in uncertainty of the measured signals. The second feature is the key distinction from the classical numerical methods. As, due to the fact that classical statement of the problem requires extra condition $\dot{\varphi}(0)$ for a stable solution, the general rule is $\dot{\varphi}(0)=0$. As a result, the features have a significant effect on numerical solution stability.

The authors changed the equation system (1) and rearranged $\ddot{x}$ and $\ddot{z}$ to the left side of the equation system. Thus, the changed system is 


$$
\left\{\begin{array}{l}
\ddot{\varphi}(t)=\frac{a_{1}(t)+a_{2}(t)+a_{3}(t)}{3 r} ; \\
\ddot{x}(t)=\frac{\ddot{\varphi}(t) r-a_{2}+\ddot{z}(t) \sin (\varphi)-g \sin (\varphi)}{\cos (\varphi)} ; \\
\ddot{z}(t)=\frac{\ddot{\varphi}(t) r-a_{3}+\ddot{x}(t) \cos \left(\varphi-\frac{\pi}{3}\right)+g \sin \left(\varphi-\frac{\pi}{3}\right)}{\sin \left(\varphi-\frac{\pi}{3}\right)} .
\end{array}\right.
$$

Based on the physical properties of the mechanical systems the authors assumed the functions $\varphi(t)$, $x(t), z(t)$ are twice continuously-differentiable in $t \in[0, T]$ for all $T>0$. Moreover, there are constants $C, K, \beta>0$ such that conditions $|\varphi(t)| \leq C e^{\beta t}$ and $\max \left\{\left|\varphi^{(3)}(t)\right|,\left|x^{(3)}(t)\right|,\left|z^{(3)}(t)\right|\right\} \leq K$ are fulfilled.

Taking into account the properties of $\varphi(t), x(t), z(t)$ the authors proposed the computational scheme based on discrete regularization method (DRM) to calculate the rotation angle. The multidimensional form of DRM was proposed in [16]. The basic principles of the DRM are regularization technique and application of finite-difference equations. The idea of the method is described hereafter.

The finite-difference grid is introduced

$$
G=\left\{t_{k} \mid t_{k}=(k-1) \tau, k=\overline{1, N_{t}+1}\right\}
$$

with time step $\tau$. As well, let $\varphi\left(t_{k}\right)=\varphi_{k}$ and measured values $a_{1}\left(t_{k}\right)=a_{1}^{k}, a_{2}\left(t_{k}\right)=a_{2}^{k}, a_{3}\left(t_{k}\right)=a_{3}^{k}$. Using the finite difference analog of the derivatives, the differential equation in (2) was replaced by a finite-difference equation

$$
\frac{\varphi_{k+1}-2 \varphi_{k}+\varphi_{k-1}}{\tau}=\frac{a_{1}^{k}+a_{2}^{k}+a_{3}^{k}}{3 r} .
$$

The differential equations from system (3) for $\ddot{x}(t)$ and $\ddot{z}(t)$ are replaced in the same way.

Additional stabilization functionals with parameters $\alpha_{1}, \alpha_{2}, \alpha_{3}$ for a stable solution are introduced into each finite-difference equation. Further, basing on continuity and differentiability of the function $\varphi(t)$ the initial conditions of $\dot{\varphi}(t), \dot{x}(t), \dot{z}(t)$ are approximated by linearized analogs.

Further, the authors chose the discretization step $\tau$ and regularization parameters according to the special conditions and calculated the rotation angle $\varphi_{k+1}$.

\section{Computational results}

The method described above has been implemented in simulation and applied to the signals of the wireless sensor with random white noise. The parameters and the initial conditions of the sensor are the same as in [15]. We assumed that the shaft moved with the accelerations (5). Also, we added the random white noise to the signals of the accelerometers of the sensor.

$$
\left\{\begin{array}{l}
\ddot{\varphi}=10 \sin (2 \pi t+\pi)+3.5 \sin (2 \pi 50 t)+1.5 \sin (2 \pi 100 t)+ \\
+1.2 \sin (2 \pi 150 t)+0.5 \sin (2 \pi 450 t)+0.25 \sin (2 \pi 455 t) ; \\
\ddot{x}=0.5 \sin (2 \pi 375 t)+0.25 \sin (2 \pi 380 t) ; \\
\ddot{z}=0.5 \sin (2 \pi 410 t)+0.25 \sin (2 \pi 400 t) .
\end{array}\right.
$$

The results of the signals processed by the numerical method were compared with the reference angle of the shaft. The reference angle of the shaft was calculated from the angular acceleration by means of numerical integration (Fig. 1). The Fig. 2 shows calculation error of the angle of the shaft by numerical method which did not exceed 0.027 rad. 


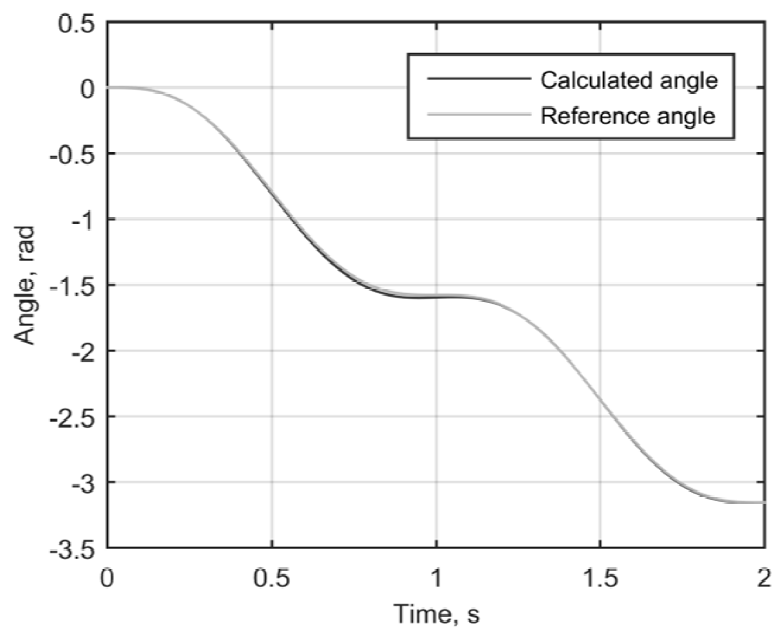

Fig. 1. The calculated and reference rotation angles

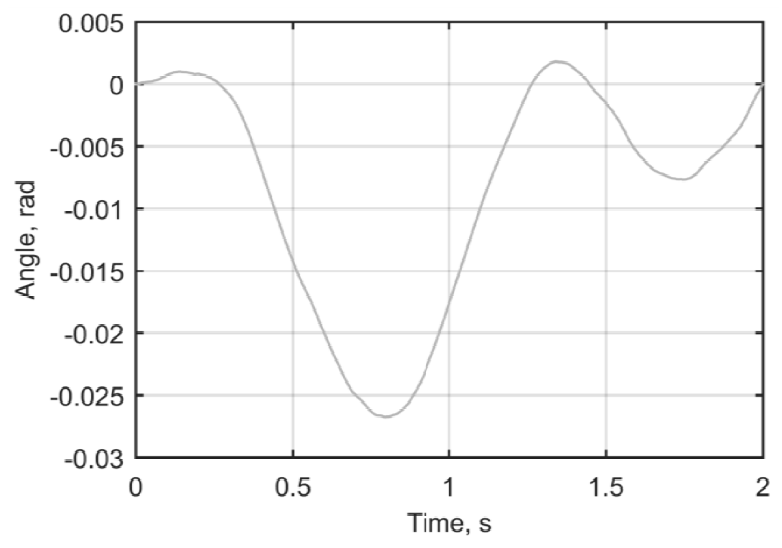

Fig. 2. The calculation error of the rotation angle by means of the numerical method

\section{Conclusion}

The calculation of the rotation angle of the shaft from the angular acceleration of the shaft is a complicated problem. The problem becomes more difficult if the angular acceleration contains noise. The computational results show that the proposed numerical method allows an increase in the accuracy of calculating the shaft rotation angle during the mechanism operation when the angular acceleration contains high noise. The future studies will analyze work of the numerical method at actual data from the wireless sensor of acceleration.

The work was supported by Act 211 Government of the Russian Federation, contract 02.A03.21.0011.

\section{References}

1. Jafarizadeh M.A., Hassannejad R., Ettefagh M.M., Chitsaz S. Asynchronous Input Gear Damage Diagnosis Using Time Averaging and Wavelet Filtering. Mech. Syst. Signal Process., 2008, vol. 22, pp. 172-201. DOI: 10.1016/j.ymssp.2007.06.006

2. Feldman M. Hilbert Transform in Vibration Analysis. Mech. Syst. Signal Process., 2011, vol. 25 (3), pp. 735-802. DOI: 10.1016/j.ymssp.2010.07.018

3. Ahamed N., Pandya Y., Parey A. Spur Gear Tooth Root Crack Detection Using Time Synchronous Averaging under Fluctuating Speed. Measurement, 2014, vol. 52, pp. 1-11. DOI: 10.1016/j.measurement.2014.02.029

4. Amarnath M., Praveen Krishna I.R. Local Fault Detection in Helical Gears via Vibration and Acoustic Signals Using EMD Based Statistical Parameter Analysis. Measurement, 2014, vol. 58, pp. 154-164. DOI: 10.1016/j.measurement.2014.08.015

5. Yang Yu, He Yigang, Cheng Junsheng, Yu Dejie. A Gear Fault Diagnosis Using Hilbert Spectrum Based on MODWPT and a Comparison with EMD Approach. Measurement, 2009, vol. 42, pp. 542-551. DOI: 10.1016/j.measurement.2008.09.011

6. Ha D., Park H., Choi S., Kim Y. A Wireless MEMS-Based Inclinometer Sensor Node for Structural Health Monitoring. Sensors, 2013, vol. 13 (12), pp. 16090-16104. DOI: 10.3390/s131216090

7. Kavitha S., Daniel R.J., Sumangala K. High Performance MEMS Accelerometers for Concrete SHM Applications and Comparison with COTS Accelerometers. Mech. Syst. Signal Process., 2016, vol. 66, pp. 410-424. DOI: 10.1016/j.ymssp.2015.06.005

8. Korkua S., Jain H., Lee W.J., Kwan C. Wireless Health Monitoring System for Vibration Detection of Induction Motors. 2010 IEEE Industiral and Commercial Power Systems Technical Conf. Conf. Record (Tallahassee, FL, USA), 2010, pp. 1-6. DOI: 10.1109/icps.2010.5489899

9. Son J., Ahn B., Ha J., Choi B. An availability of MEMS-Based Accelerometers and Current Sensors in Machinery Fault Diagnosis. Measurement, 2016, vol. 94, pp. 680-691. 
10. Sinitsin (Jr.) V.V., Sinitsin V.V., Semenov A.S., Shestakov A.L. Ustroystvo izmereniya vibrouskoreniya podvizhnykh elementov mashin i mekhanizmov [Acceleration Measuring Device Moving Parts of Machines and Mechanisms]. Patent RU 142934 U1, Bull. no. 19, Publ. 10.07.2014.

11. Chinchalkar S. Determination of Crack Location in Beams Using Natural Frequencies. Journal of Sound and Vibration, 2001, vol. 247, iss. 3, pp. 417-429. DOI: 10.1006/jsvi.2001.3748

12. Zhang Z., Shankar K., Ray T., Morozov E.V., Tahtali M. Vibration-Based Inverse Algorithms for Detection of Delamination in Composites. Composite Structures, 2013, vol. 102, pp. 226-236. DOI: 10.1016/j.compstruct.2013.03.012

13. Jang T.S., Choi Hang S., Han S.L. A New Method for Detecting Non-linear Damping and Restoring Forces in Non-Linear Oscillation Systems from Transient Data. International Journal of NonLinear Mechanics, 2009, vol. 44, iss. 7, pp. 801-808. DOI: 10.1016/j.ijnonlinmec.2009.05.001

14. Parand K., Abbasbandy S., Kazem S., Rad J.A. A Novel Application of Radial Basis Functions for Solving a Model of First-Order Integro-Ordinary Differential Equation. Communications in Nonlinear Science and Numerical Simulation, 2011, vol. 16, iss. 11, pp.4250-4258. DOI: 10.1016/j.cnsns.2011.02.020

15. Sinitsin V.V., Shestakov A.L. Wireless Acceleration Sensor of Moving Elements for Condition Monitoring of Mechanisms. Meas. Sci. Technol., 2017, vol. 28, no. 9, pp. 1-8. DOI: 10.1088/1361-6501/aa7ab6

16. Yaparova N.M., Shestakov A.L. Method for Temperature Measuring Inside a Cylindrical Body Based on Surface Measurements. $14^{\text {th }}$ IMEKO TC10 Workshop Technical Diagnostics, Italy, 2016, pp. 8-12.

\title{
НОВЫЙ ЧИСЛЕННЫЙ МЕТОД ОПРЕДЕЛЕНИЯ УГЛА ПОВОРОТА ВАЛА ИЗ УСКОРЕНИЙ БЕСПРОВОДНОГО ДАТЧИКА
}

\author{
В.В. Синицин, Н.М. Япарова \\ Южно-Уральский государственный университет, г. Челябинск, Россия
}

\begin{abstract}
Хотя плановое регламентное техническое обслуживание позволяет предотвратить выход из строя и незапланированные простои оборудования, такой подход ограничивает гибкость производственных систем. С другой стороны, концепция технического обслуживания по состоянию повышает гибкость производственных систем, однако требует надежной диагностической информации в режиме реального времени. Современные технологии, например, беспроводная передача энергии и концепция индустриального интернета вещей расширяют возможности существующих решений, а также позволяют реализовать новые высокочувствительные датчики для технического контроля, такие как беспроводной датчик ускорений, который закрепляют непосредственно на вращающемся валу механизма. Такой беспроводной датчик одновременно измеряет угловое и линейные ускорения вала, а также мгновенный угол его поворота. Кроме того, беспроводной датчик содержит высокопроизводительный микроконтроллер, который позволяет обрабатывать измеренные данные в режиме реального времени и, таким образом, оценивать состояние узла механизма. Однако точность измерения угла поворота вала беспроводным датчиком ограничивает точность его измерений линейных ускорений вала. В этой статье авторы предлагают новый численный метод, который позволяет повысить точность измерения угла поворота и линейных ускорений вала. Метод основан на методе регуляризации и применении конечно-разностных уравнений. Кроме того, в исследовании показаны результаты применения численного метода для расчета угла поворота вала из
\end{abstract}




\section{Краткие сообщения}

моделированных сигналов беспроводного датчика ускорений, содержащих шум. Результаты моделирования показывают, что численный метод эффективно определяет угол поворота и, более того, метод устойчив к шуму.

Ключевые слова: угловое ускорение, вращающийся вал, беспроводной сенсор, численный метод, метод регуляризачии, обратная задача.

Работа выполнена при поддержке Постановления 211 Правительства РФ, контракт 02.A03.21.0011.

\section{Лumepamypa}

1. Asynchronous Input Gear Damage Diagnosis Using Time Averaging and Wavelet Filtering / M.A. Jafarizadeh, R. Hassannejad, M.M. Ettefagh, S. Chitsaz // Mech. Syst. Signal Process. - 2008. Vol. 22. - P. 172-201. DOI: 10.1016/j.ymssp.2007.06.006

2. Feldman, M. Hilbert Transform in Vibration Analysis / M. Feldman // Mech. Syst. Signal Process. - 2011. - Vol. 25 (3). - P. 735-802. DOI: 10.1016/j.ymssp.2010.07.018

3. Ahamed, N. Spur Gear Tooth Root Crack Detection Using Time Synchronous Averaging under Fluctuating Speed / N. Ahamed, Y. Pandya, A. Parey // Measurement. - 2014. - Vol. 52. - P. 1-11. DOI: 10.1016/j.measurement.2014.02.029

4. Amarnath, M. Local Fault Detection in Helical Gears via Vibration and Acoustic Signals Using EMD Based Statistical Parameter Analysis / M. Amarnath, I.R. Praveen Krishna // Measurement. 2014. - Vol. 58. - P. 154-164. DOI: 10.1016/j.measurement.2014.08.015

5. A Gear Fault Diagnosis Using Hilbert Spectrum Based on MODWPT and a Comparison with EMD Approach / Yang Yu, He Yigang, Cheng Junsheng, Yu Dejie // Measurement. - 2009. - Vol. 42. P. 542-551. DOI: 10.1016/j.measurement.2008.09.011

6. A Wireless MEMS-Based Inclinometer Sensor Node for Structural Health Monitoring / D. Ha, H. Park, S. Choi, Y. Kim // Sensors. - 2013. - Vol. 13 (12). - P. 16090-16104. DOI: 10.3390/s131216090

7. Kavitha, S. High Performance MEMS Accelerometers for Concrete SHM Applications and Comparison with COTS Accelerometers / S. Kavitha, R.J. Daniel, K. Sumangala // Mech. Syst. Signal Process. - 2016. - Vol. 66. - P. 410-424. DOI: 10.1016/j.ymssp.2015.06.005

8. Wireless Health Monitoring System for Vibration Detection of Induction Motors / S. Korkua, H. Jain, W.J. Lee, C. Kwan // 2010 IEEE Industiral and Commercial Power Systems Technical Conf. Conf. Record (Tallahassee, FL, USA). - 2010. - P. 1-6. DOI: 10.1109/icps.2010.5489899

9. An Availability of MEMS-Based Accelerometers and Current Sensors in Machinery Fault Diagnosis / J. Son, B. Ahn, J. Ha, B. Choi // Measurement. - 2016. - Vol. 94. - P. 680-691.

10. Патент на полезную модель 142934 Российская Федеращия, МПК7 G 01 P 15/02, G 01 Н 9/00. Устройство измерения виброускорения подвижных элементов машин и механизмов / В.В. Синицин, В.В. Синицин, А.С. Семенов, А.Л. Шестаков; заявитель и патентообладатель ФГБОУ ВПО «ЮУрГУ» (НИУ). - № 2014109714/28; заявл. 12.03.2014; опубл. 10.07.2014, Бюл. № 19.

11. Chinchalkar, S. Determination of Crack Location in Beams Using Natural Frequencies / S. Chinchalkar // Journal of Sound and Vibration. - 2001. - Vol. 247, iss. 3. - P. 417-429. DOI: 10.1006/jsvi.2001.3748

12. Vibration-Based Inverse Algorithms for Detection of Delamination in Composites / Z. Zhang, K. Shankar, T. Ray et al. // Composite Structures. - 2013. - Vol. 102. - P. 226-236. DOI: 10.1016/j.compstruct.2013.03.012

13. Jang, T.S. A New Method for Detecting Non-linear Damping and Restoring Forces in NonLinear Oscillation Systems from Transient Data / T.S. Jang, S. Choi Hang, S.L. Han // International Journal of Non-Linear Mechanics. - 2009. - Vol. 44, iss. 7. - P. 801-808. DOI: 10.1016/j.ijnonlinmec.2009.05.001

14. A Novel Application of Radial Basis Functions for Solving a Model of First-Order IntegroOrdinary Differential Equation / K. Parand, S. Abbasbandy, S. Kazem, J.A. Rad // Communications in Nonlinear Science and Numerical Simulation. - 2011. - Vol. 16, iss. 11. - P. 4250-4258. DOI: 10.1016/j.cnsns.2011.02.020

15. Sinitsin, V.V. Wireless Acceleration Sensor of Moving Elements for Condition Monitoring of 
Mechanisms / V.V. Sinitsin, A.L. Shestakov // Meas. Sci. Technol. - 2017. - Vol. 28, no. 9. - P. 1-8. DOI: 10.1088/1361-6501/aa7ab6

16. Yaparova, N.M. Method for Temperature Measuring Inside a Cylindrical Body Based on Surface Measurements / N.M. Yaparova, A.L. Shestakov // $14^{\text {th }}$ IMEKO TC10 Workshop Technical Diagnostics, Italy. - 2016. - P. 8-12.

Синицин Владимир Владимирович, инженер-исследователь управления научной и инновационной деятельности, Южно-Уральский государственный университет, г. Челябинск; sinitsinvv@susu.ru.

Япарова Наталья Михайловна, канд. физ.-мат. наук, зав. кафедрой вычислительной математики и высокопроизводительных вычислений, Южно-Уральский государственный университет, г. Челябинск; iaparovanm@susu.ru.

Поступила в редакцию 15 мая 2018 г.

\section{ОБРАЗЕЦ ЦИТИРОВАНИЯ}

Sinitsin, V.V. Determination of Shaft Rotation Angle from Accelerations of the Wireless Sensor by the Novel Numerical Method / V.V. Sinitsin, N.M. Yaparova // Вестник ЮУрГУ. Серия «Компьютерные технологии, управление, радиоэлектроника». - 2018. - Т. 18, № 3. C. $143-149$. DOI: $10.14529 /$ ctcr180315

\section{FOR CITATION}

Sinitsin V.V., Yaparova N.M. Determination of Shaft Rotation Angle from Accelerations of the Wireless Sensor by the Novel Numerical Method. Bulletin of the South Ural State University. Ser. Computer Technologies, Automatic Control, Radio Electronics, 2018, vol. 18 , no. 3 , pp. 143-149. DOI: $10.14529 /$ ctcr180315 